\title{
LEARNING DEVELOPMENT ORIENTED ON CHARACTER EDUCATION STRENGTHENING
}

\author{
Sri Mulyanti \\ Universitas Suryakancana Cianjur \\ email: srimulyanti41@yahoo.com \\ srimulyanti247@gmail.com
}

\begin{abstract}
This article describes the development of learning steps oriented towards strengthening character education. The material used in learning is "Text Report Experiments". The development of learning steps is prepared to provide convenience to Indonesian language teachers in formulating the lesson plan and in implementing it in the classroom. The research uses a development method that focuses on efforts to produce and validate a learning model, especially learning implementation activities that are in the lesson plan made by Indonesian language teachers Class IX. The products developed in the study are steps in Indonesian language learning especially with regard to text reporting experiments. The results of the study were in the form of developing learning steps in detail and contained the values of strengthening character education. The results of the study are expected to facilitate teachers in carrying out Indonesian language learning and also facilitate in preparing lesson plans. In addition, learning Indonesian using this development model is expected to encourage students to have good communication competencies and character.
\end{abstract}

Keywords: learning steps, lesson plan, character education.

\section{PENDAHULUAN}

Tugas utama seorang guru adalah mengajar. Guru dituntut kreatif dalam merancang pembelajaran guna diimplementasikan di dalam kelas. Kreativitas tersebut perlu mampu membuat siswa belajar secara optimal sesuai denga tujuan pembelajaran bahasa Indonesia. Oleh karena itu, guru perlu mampu mengembangan pembelajaran yang terstruktur baik hingga memudahkan dalam perencanaan dan pelaksanaannya. Keberadaan RPP khususnya mata pelajaran Bahasa Indonesia dapat membantu guru dalam pelaksanaan pembelajaran.

Berdasarkan hasil wawancara dengan guru bahasa Indonesia di Kabupaten Cianjur masih banyak guru yang mengalami kesulitan dalam menyusun RPP terutama merencanakan tahapan-tahapan dalam langkah pembelajaran, apalagi merancang pembelajaran yang sesuai dengan kurikulum 2013 dan terintegrasi dengan pendidikan karakter. Sebagian guru mengambil langkah dengan meniru rancangan pembelajaran yang ada di buku nonteks yang tersedia di pasaran. Hal ini tidak salah, akan tetapi perlu diingat bahwa kondisi dan karakteristik siswa perlu menjadi bahan pertimbangan dalam membuat rancangan pembelajaran.

Artikel ini akan memaparkan bagaimana langkah-langkah pembelajaran bahasa Indonesia khusus mengenai materi teks melaporkan percobaan yang teritegrasi dengan nilai-nilai PPK dalam perencanaan dan pelaksanaan pembelajaran berdasarkan kurikulum 2013. Dengan demikian, diharapkan dapat memberi kemudahan kepada guru bahasa Indonesia dalam perencanaan dan pelaksanaan pembelajaran bahasa Indonesia khusus mengenai materi teks melaporkan percobaan yang teritegrasi dengan nilai-nilai PPK yang mengacu pada Kurikulum 2013. 
Selain itu, diharapkan juga dapat memberi manfaat kepada guru mata pelajaran bahasa Indonesia dalam merencanakan dan melaksanakan pembelajaran bahasa Indonesia khususnya berkenaan dengan teks melaporkan percobaan yang terintegrasi dengan nilainilai PPK dan berdasarkan Kurikulum 2013.

Selanjutnya, perlu juga dikemukakan bahwa mata pelajaran bahasa Indonesia itu memiliki keistimewaan karena pelajaran bahasa Indonesia diberikan/diajarkan kepada siswa dari mulai kelas 1 (satu) sampai kelas 12 (dua belas). Selain itu, bahasa Indonesia menjadi mata kuliah wajib umum di perguruan tinggi.

Tujuan pembelajaran bahasa Indonesia di antaranya agar siswa mampu berkomunikasi baik lisan maupun tulis secara efektif, efisien, dan menggunakan etika yanga baik. Selain itu, siswa diharapkan bersikap positip terhadap bahasa Indonesia, bangga dan menghargai sastra Indonesia. Untuk mencapai tujuan pembelajaran tersebut, dalam pelaksanan pembelajaran di dalam kelas, guru bahasa Indonesia merancang RPP.

Dalam Peraturan Menteri Pendidikan dan Kebudayaan Nomor 22 Tahun 2016 Tentang Standar Proses Pendidikan Dasar dan Menengah disebutkan Rencana Pelaksanaan Pembelajaran (RPP) adalah rencana kegiatan pembelajaran tatap muka untuk satu pertemuan atau lebih. RPP dikembangkan dari silabus untuk mengarahkan kegiatan pembelajaran peserta didik dalam upaya mencapai kompetensi dasar (KD). Setiap pendidik pada satuan pendidikan berkewajiban menyusun RPP secara lengkap dan sistematis agar pembelajaran berlangsung secara interaktif, inspiratif, menyenangkan, menantang, efisien, memotivasi peserta didik untuk berpartisipasi aktif, serta memberikan ruang yang cukup bagi prakarsa, kreativitas, dan kemandirian sesuai dengan bakat, minat, dan perkembangan fisik serta psikologis peserta didik. RPP disusun berdasarkan KD atau subtema yang dilaksanakan satu kali pertemuan atau lebih.
Lebih lanjut dalam permendikbud tersebut dijelaskan pula komponen-komponen RPP. RPP yang dikembangkan secara rinci mengacu pada silabus, buku teks pelajaran, dan buku panduan guru. RPP merupakan panduan bagi guru dalam melaksanakan pembelajaran Bahasa Indonesia guna mencapai tujuan yang diharapkan.

Menyusun RPP merupakan salah satu kegiatan wajib dilakukan guru sebelum memulai pembelajaran di samping kegiatan membaca buku referensi, memperluas wawasan, mengidentifikasi sumber-sumber belajar yang relevan, dan menentukan langkah-langkah pembelajaran. RPP dikembangkan pada setiap awal semester atau awal tahun pelajaran. Ini dimaksudkan agar RPP telah tersedia terlebih dahulu dalam setiap awal pelaksanaan pembelajaran (Purwantini dkk., 2017:1).

Salah satu bagian penting dalam RPP adalah pelaksanaan pembelajaran. Peraturan Menteri Pendidikan dan Kebudayaan Nomor 22 Tahun 2016 Tentang Standar Proses Pendidikan Dasar dan Menengah menjelaskan kegiatan pelaksanaan pembelajaran meliputi pendahuluan, inti, dan penutup. Dalam kegiatan pendahuluan, guru wajib: a) menyiapkan peserta didik secara psikis dan fisik untuk mengikuti proses pembelajaran; b) memberi motivasi belajar peserta didik secara kontekstual sesuai manfaat dan aplikasi materi ajar dalam kehidupan sehari-hari, dengan memberikan contoh dan perbandingan lokal, nasional dan internasional, serta disesuaikan dengan karakteristik dan jenjang peserta didik; c) mengajukan pertanyaanpertanyaan yang mengaitkan pengetahuan sebelumnya dengan materi yang akan dipelajari; d) menjelaskan tujuan pembelajaran atau kompetensi dasar yang akan dicapai; dan e) menyampaikan cakupan materi dan penjelasan uraian kegiatan sesuai silabus.

Pelaksanaan pembelajaran berikutnya adalah kegiatan inti. Dalam kegiatan inti menggunakan model pembelajaran, metode 
pembelajaran, media pembelajaran, dan sumber belajar yang disesuaikan dengan karakteristik peserta didik dan mata pelajaran. Pemilihan pendekatan tematik dan /atau tematik terpadu dan/atau saintifik dan/atau inkuiri dan penyingkapan (discovery) dan/ atau pembelajaran yang menghasilkan karya berbasis pemecahan masalah (project based learning) disesuaikan dengan karakteristik kompetensi dan jenjang pendidikan.

Hal yang perlu diperhatikan dalam kegiatan inti adalah memperhatikan sikap, pengetahuan, dan keterampilan. Sesuai dengan karakteristik sikap, maka salah satu alternatif yang dipilih adalah proses afeksi mulai dari menerima, menjalankan, menghargai, menghayati, hingga mengamalkan. Seluruh aktivitas pembelajaran berorientasi pada tahapan kompetensi yang mendorong peserta didik untuk melakuan aktivitas tersebut. Pengetahuan dimiliki melalui aktivitas mengetahui, memahami, menerapkan, menganalisis, mengevaluasi, hingga mencipta.

Karakteritik aktivititas belajar dalam domain pengetahuan ini memiliki perbedaan dan kesamaan dengan aktivitas belajar dalam domain keterampilan. Untuk memperkuat pendekatan saintifik, tematik terpadu, dan tematik sangat disarankan untuk menerapkan belajar berbasis penyingkapan/penelitian (discovery/inquiry learning).

Untuk mendorong peserta didik menghasilkan karya kreatif dan kontekstual, baik individual maupun kelompok, disarankan yang menghasilkan karya berbasis pemecahan masalah (project based learning). Keterampilan diperoleh melalui kegiatan mengamati, menanya, mencoba, menalar, menyaji, dan mencipta.

Seluruh isi materi (topik dan sub topik) mata pelajaran yang diturunkan dari keterampilan perlu mendorong peserta didik untuk melakukan proses pengamatan hingga penciptaan. Untuk mewujudkan keterampilan tersebut perlu melakukan pembelajaran yang menerapkan modus belajar berbasis penyingkapan/penelitian (discovery/inquiry learning) dan pembelajaran yang menghasilkan karya berbasis pemecahan masalah (project based learning).

Terakhir adalah kegiatan penutup. Dalam kegiatan penutup, guru bersama peserta didik baik secara individual maupun kelompok melakukan refleksi untuk mengevaluasi: a) seluruh rangkaian aktivitas pembelajaran dan hasil-hasil yang diperoleh untuk selanjutnya secara bersama menemukan manfaat langsung maupun tidak langsung dari hasil pembelajaran yang telah berlangsung; b) memberikan umpan balik terhadap proses dan hasil pembelajaran; c) melakukan kegiatan tindak lanjut dalam bentuk pemberian tugas, baik tugas individual maupun kelompok; dan d) menginformasikan rencana kegiatan pembelajaran untuk pertemuan berikutnya.

Sesuai dengan Kurikulum 2013, pembelajaran bahasa Indonesia menggunakan pendekatan berbasis teks. Teks merupakan satu kesatuan makna dan dipengaruhi oleh konteks situasi dan konteks budaya (Emilia, 2016:26). Mahsun (2014:1) mendefinisikan teks sebagai satuan bahasa yang digunakan sebagai ungkapan suatu kegiatan sosial baik secara lisan maupun tulis dengan struktur berpikir yang lengkap. Selanjutnya Harsiati dkk. (2016:iii) menjelaskan berkenaan dengan pendekatan pembelajaran bahasa Indonesia yaitu pembelajaran Bahasa Indonesia dikembangkan berdasarkan pendekatan komunikatif, pendekatan berbasis teks, pendekatan CLIL (content language integrated learning), pendekatan pendidikan karakter, dan pendekatan literasi. Content Language Integrated Learning menonjolkan empat unsur penting sebagai penajaman pengertian kompetensi berbahasa, yaitu isi (content), bahasa/komunikasi (communication), kognisi (cognition), dan budaya (culture).

Selain itu, dijelaskan pula oleh Harsiati dkk. (2016: 4) bahwa teks dalam pendekatan 
berbasis genre bukan diartikan istilah umum sebagai tulisan berbentuk artikel. Teks merupakan kegiatan sosial, tujuan sosial. Ada 7 (tujuh) jenis teks sebagai tujuan sosial, yaitu: laporan (report), rekon (recount), eksplanasi (explanation), eksposisi (exposition: discussion, response or review), deskripsi (description), prosedur (procedure), dan narasi (narrative). Lokasi sosial dari eksplanasi bisa berupa berita, ilmiah populer, paparan tentang sesuatu; naratif bisa berupa bercerita, cerita, dan sejenisnya; eksposisi bisa berupa pidato/ceramah (eksemplum ada dalam pidato atau tulisan persuasif), surat pembaca, debat.

Pembelajaran bahasa Indonesia berbasis teks memiliki empat tahap/prosedur penting dalam pelaksanaan pembelajaran meliputi (1) membangun konteks teks dan membangun pengetahuan tentang teks yang akan dipelajari, (2) telaah model (dekonstruksi), (3) latihan membuat teks secara bertahap dan terbimbing (joint construction), (4) tugas dan latihan membuat teks secara mandiri dan minim bantuan guru (independent construction) (Harsiati, 2016:7).

Teks laporan (report) sebuah teks yang mengandung klarifikasi mengenai suatu objek tertentu yang berdasarkan kriteria tertentu. Teks laporan percobaan adalah suatu teks yang berisi tentang percobaan yang dilakukan oleh penulis yang biasa berada ketika seseorang melakukan suatu percobaan, observasi atau melakukan karya ilmiah dan bisa juga pada laporan praktikum. (http://smkpenanusantara.blogspot.com/2016/ 12/pengertian-teks-laporan-struktur teks.html).

Emilia (2016:98) menyebutkan report (descriptive report) merupakan jenis teks yang menyajikan informasi dengan jelas dan singkat). Secara umum, teks laporan percobaan memiliki ciri: 1) melaporkan hasil percobaan; 2) percobaan ilmiah dilakukan untuk menguji sesuatu; 3) diawali dengan memaparkan tujuan percobaan; 4) memaparkan bahan dan alat yang diperlukan; 5) memaparkan prosedur melaksanakan percobaan; 6) pencatatan hasil percobaan; 7) diakhiri dengan pemaparan simpulan hasil percobaan berdasarkan hasil analisis terhadap data hasil pengamatan. Selanjutnya, ciri kebahasaan teks laporan percobaan meliputi kata tugas, kata benda, kata kerja teknis, dan kalimat aktif. Struktur teks laporan percobaan terdiri dari judul, tujuan, bahan dan alat, langkah-langkah percobaan, hasil percobaan, dan simpulan.

Pembelajaran bahasa Indonesia bertujuan membina dan mengembangkan pengetahuan dan keterampilan berkomunikasi yang dibutuhkan peserta didik dalam menempuh pendidikan dan di dunia kerja. Selain itu, pembelajaran bahasa Indonesia bisa dijadikan wahana penanaman nilai-nilai budi pekerti atau karakter bangsa seperti yang diaparkan dalam Permendikbud No. 23 Tahun 2015.

Gerakan Penguatan Pendidikan Karakter (PPK) merupakan kelanjutan gerakan nasional pendidikan karakter bangsa tahun 2010. Program PPK bertujuan memperkuat pembentukan karakter siswa yang selama ini sudah dilakukan di banyak sekolah. Salah satu implementasi gerakan PPK dengan cara mengintegrasikan pada mata pelajaran. Pentingnya integrasi nilai-nilai pendidikan karakter dalam pembelajaran bahasa Indonesia dikarenakan hal ini merupakan bagian dukungan terhadap program Nawacita yaitu Revolusi Karakter Bangsa dan Gerakan Revolusi Mental dalam Pendidikan.

Pendidikan karakter merupakan sebuah upaya dan proses membentuk dan menanamkan nilai-nilai karakter pada seseorang/ siswa melalui pendidikan. Hasil pendidikan tersebut terlihat dalam tindakan nyata seseorang, yaitu tingkah laku yang baik, jujur, bertanggung jawab, kerja keras, menghormati hak orang lain, dan sebagainya, karena potensi yang ada dalam diri manusia perlu dikembangkan. Selain itu pendidikan karakter juga merupakan kinerja sebuah lembaga pendidikan mencakup proses pembiasaan tentang perilaku yang baik (olah hati, olah 
pikir, olah raga dan kinestetik, olah rasa dan karsa), bertujuan mengembangkan kemampuan peserta didik untuk memberikan keputusan baik-buruk, memelihara hal-hal yang baik, dan mengimplementasikan kebaikan itu dalam kehidupan sehari-hari tanpa paksaan atau dengan sepenuh hati (Mulyanti, 2012).

Memposisikan karakter dalam pembelajaran bersamaan atau berdampingan dengan keutamaan intelektualitas merupakan hal yang ideal. Disampaikan Kemdikbud (2017:4) bahwa pada dasarnya pendidikan bertujuan mengembangkan potensi-potensi intelektual dan karakter peserta didik. Jauh sebelumnya, pemikiran Ki Hajar Dewantara sudah sangat inovatif dan sesuai dengan kebutuhan pada saat ini. Dikatakan bahwa pendidikan adalah daya upaya untuk memajukan bertumbuhnya budi pekerti (kekuatan batin, karakter), pikiran (intellect) dan tubuh anak. Bagian-bagian itu tidak boleh dipisahkan agar kita dapat memajukan kesempurnaan hidup anak-anak kita (Karya Ki Hadjar Dewantara Buku I: Pendidikan dalam Kemdikbud, 2017:5). Ditegaskan dalam Undang-Undang Nomor 20 Tahun 2003 tentang Sistem Pendidikan Nasional bahwa "Pendidikan nasional berfungsi mengembangkan kemampuan dan membentuk watak serta peradaban bangsa yang bermartabat dalam rangka mencerdaskan kehidupan bangsa, bertujuan untuk berkembangnya potensi peserta didik agar menjadi manusia yang beriman dan bertakwa kepada Tuhan Yang Maha Esa, berakhlak mulia, sehat, berilmu, cakap, kreatif, mandiri, dan menjadi warga negara yang demokratis serta bertanggung jawab". Peraturan Pemerintah Nomor 19 Tahun 2005 tentang Standar Nasional Pendidikan (SNP) mendeskripsikan secara tersurat berbagai kompetensi yang bersangkutan dengan karakter di samping intelektualitas. Ini berati sesungguhnya pendidikan bertugas mengembangkan karakter sekaligus intelektualitas berupa kompetensi peserta didik.

Nilai-nilai utama dalam PPK yaitu religius (beriman bertakwa, bersih, toleransi,cinta lingkungan), nasionalis (cinta tanah air, semangat kebangsaan, menghargai kebhinnekaan), mandiri (kerja keras, kreatif, disiplin, mandiri, pembelajar), gotong royong (kerja sama, solidaritas, saling menolong, kekeluargaan) dan integritas (kejujuran, keteladanan, kesantunan, cinta pada kebenaran) (Kemdikbud, 2017). Nilai-nilai tersebut akan diintegrasikan dalam pelaksanaan pembelajaran bahasa Indonesia materi teks melaporkan percobaan.

\section{METODE}

Penelitian dilakukan dengan menggunakan metode penelitian dan pengembangan yang berfokus pada upaya memproduksi dan memvalidasi suatu model pendidikan yakni kegiatan pembelajaran khususnya berupa pelaksanaan pembelajaran dalam RPP yang disusun guru Bahasa Indonesia SMPN 1 Cianjur kelas IX materi teks melaporkan percobaan.

Produk yang dikembangkan dalam penelitian adalah pengembangan pelaksanaan pembelajaran bahasa Indonesia terintegrasi nilai-nilai PPK. Desain pengembangan ini diharapkan mampu membantu sekaligus memudahkan guru dalam merencanakan dan melaksanakan pembelajaran bahasa Indonesia yang terintegrasi dengan nilai-nilai PPK sehingga hasil belajar bahasa Indonesia siswa meningkat dan sekaligus memiliki karakter yang baik.

Terdapat 10 (sepuluh) langkah penelitian pengembangan menurut Borg \&Gall (1989:775) yaitu research and information, planning, develop preliminary, preliminary form of product, main product revision, main field testing, operational product revision, operational field testing, final product revision, dan disseminaton and implementation. Dari sepuluh langkah penelitian pengembangan yang dikemukakan Borg \& Gal tersebut, dalam penelitian hanya digunakan tiga langkah yaitu research and information (penelitian dan pengumpulan 
Informasi), planning (perencanaan) dan develop preliminary (pengembangan produk).

Pada tahap research and information (penelitian dan pengumpulan informasi), dilakukan analisis kebutuhan di lapangan berupa wawancara kepada guru bahasa Indonesia kelas IX tentang pelaksanaan kegiatan pembelajaran dalam RPP yang disusun oleh guru. Selanjutnya pada tahap planning (perencanan) kegiatan yang dilakukan di antaranya merencanakan langkahlangkah pembelajaran Bahasa Indonesia yang sesuai dengan kebutuhan guru, sesuai dengan Permendikbud Nomor 22 Tahun 2016 Tentang Standar Proses Pendidikan Dasar dan Menengah, dan sesuai dengan amanat dalam Permendikbud no 23 tahun 2015 dan program Nawacita butir 8 tentang gerakan revolusi mental salah satunya dengan cara pengembangan pendidikan karakter, yaitu dengan mengintegrasikan nilai-nilai PPK dalam pembelajaran bahasa Indonesia. Terakhir develop preliminary (pengembangan produk), setetah referensi yang diperlukan terkumpul, dibuatlah kegiatan pembelajaran berupa langkah langkah pembelajaran bahasa Indonesia yang terintegrasi dengan PPK. Langkah-langkah pembelajaran disesuaikan dengan Kurikulum 2013. Hasil akhir divalidasi oleh ahlli/pakar.

\section{HASIL DAN PEMBAHASAN}

\section{Deskripsi Data}

Hasil wawancara dengan guru bahasa Indonesia diperoleh informasi bahwa dalam menjabarkan pelaksanaan pembelajaran, guru Bahasa Indonesia lebih menyukai simpel, tidak panjang lebar. Satu hal yang masih menjadi keluhan adalah kurang pahamnya menjabarkan nilai-nilai karakter dalam langkah-langklah pembelajaran.

Berikut salah satu contoh pelaksanaan pembelajaran yang terangkum dalam RPP buatan guru khusus mengenai materi teks melaporkan percobaan yang akan dikembangkan dengan integrasi nilai-nilai PPK.

\section{KEGIATAN PEMBELAJARAN}

1. Pertemuan Pertama (3 JP)

a. Kegiatan Pendahuluan (10 menit)

1) Perserta didik merespon salam dan pertanyaan dari guru berhubungan dengan kondisi kelas.

2) Perserta didik merespon pertanyaan dari guru tentang keterkaitan pengetahuan yang diperolehnya dengan materi yang akan dipelajari.

3) Perserta didik disiapkan untuk mengikuti pelajaran tentang teks laporan percobaan.

4) Perserta didik menerima informasi tentang tujuan pembelajaran dan manfaat pembelajaran.

5) Perserta didik menyimak pencapaian cakupan materi dan penjelasan uraian kegiatan pembelajaran

b. Kegiatan Inti (60 menit)

1) Mengamati

Peserta didik mencermati tayangan teks kaporan percobaan" Laporan Praktikum Jaringan Xilem'

2) Menanya

Peserta didikbertanya tentang halhal yang berkaitan teks laporan percobaan

(Pertanyaan yang dikemukakan oleh peserta didik dapat menggunakan kata tanya siapa, apa, mengapa, dimana, kapan, berapa, dan bagaimana)

3) Mengumpulkan informasi

- Secara berkelompok peserta didik mencari informasi tentang struktur teks laporan percobaan

- Peserta didik mencatat ciri kebahasaan yang terdpat pada teks laporan percobaan “ Laporan Praktikum Jaringan Xilem 
c. Penutup (10 menit)

1) Peserta didik dibimbing oleh guru melakukan refleksi terkait pembelajaran yang telah berlangsung (struktur teks tanggapan kritis)

2) Peserta didik dibimbing oleh guru membuat kesimpulan terkait pembelajaran yang telah berlangsung (penyusunan teks tanggapan kritis)

3) Peserta didik menyimak informasi tentang materipembelajaran yang akandipelajaripadapertemuanberik utnya

Kegiatan (pelaksanaan) pembelajaran yang disusun oleh guru Bahasa Indonesia tersebut, secara umum sudah sesuai dengan tuntutan Permendikbud No. 22 Tahun 2016. Dalam kegiatan pendahuluan, guru sudah melaksanakan kewajibannya berupa menyiapkan peserta didik secara psikis dan fisik untuk mengikuti proses pembelajaran; mengajukan pertanyaan-pertanyaan yang mengaitkan pengetahuan sebelumnya dengan materi yang akan dipelajari; menjelaskan tujuan pembelajaran atau kompetensi dasar yang akan dicapai; dan menyampaikan cakupan materi dan penjelasan uraian kegiatan sesuai silabus.

Hanya satu hal yang belum sesuai dengan permendikbud di atas yaitu guru belum memasukkan kegiatan memberi motivasi belajar peserta didik secara kontekstual sesuai manfaat dan aplikasi materi ajar dalam kehidupan sehari-hari, dengan memberikan contoh dan perbandingan lokal, nasional dan internasional, serta disesuaikan dengan karakteristik dan jenjang peserta didik. Kegiatan pendahuluan dalam pelaksanaan pembelajaran juga belum tampak secara tersurat integrasi nilai-nilai PPK

Kegiatan inti dalam pelaksanaan pembelajaran di atas sudah memenuhi tuntutan Kurikulum 2013. Salah satunya tampak dalam langkah-langkah pembelajaran berupa mengamati, menanya, dan mengumpulkan informasi. Aktivitas berkenaan dengan pengembangan nilai-nilai PPK belum tampak.
Kegiatan penutup dalam pelaksanaan pembelajaran sudah memenuhi standar berupa dilaksanakannya refleksi dan evaluasi yang dilakukan guru dan peserta didik meliputi kesimpulan pembelajaran dan menginformasikan rencana pembelajaran pada pertemuan berikutnya. Bagian yang tidak muncul dalam kegiatan penutup ini adalah adanya umpan balik. Secara tertulis dalam kegiatan penutup ini belum tampak integrasi nilai-nilai PPK

\section{Pengembangan Pelaksanaan Pembelajaran}

Seperti sudah dipaparkan di atas bahwa kegiatan pembelajaran yang disusun oleh guru Bahasa Indonesia kelas IX SMPN 1 Cianjur secara umum sudah baik dan sesuai dengan Permendikbud No. 22 tahun 2016. Akan tetapi, integrasi nilai-nilai PPK dalam kegiatan pembelajaran tersebut masih belum tampak.

Berikut dipaparkan pengembangan pelaksanaan pembelajaran teks melaporkan percobaan berorientasi PPK.

\section{KEGIATAN PEMBELAJARAN}

\section{Pertemuan Pertama (3 JP)}

\section{Kegiatan Pendahuluan (10 menit)}

(1) Salah seorang peserta didik memimpin doa sesuai dengan agama dan kepercayaan masing-masing.

(2) Guru memeriksa kehadiran dan menanyakan peserta didik yang tidak hadir pada hari itu beserta alasannya kepada ketua kelas/sekretaris kelas, jika ada yang sakit, guru dan para siswa medoakan agar siswa yang sakit cepat sembuh.

(3) Guru mengajak siswa untuk senantiasa bersyukur atas kesehatan, cuaca/udara yang dianugerahkan Allah SWT.

(4) Guru mengajak siswa untuk mensyukuri bahasa Indonesia dan banyaknya bahasa daerah yang ada di Indonesia dan mengajak untuk 
senantiasa bersikap positif pada bahasa Indonesia dan melestarikan bahasa daerah.

(5) Peserta didik bersama guru memeriksa kebersihan kelas.

(6) Perserta didik disiapkan untuk mengikuti pelajaran tentang teks laporan percobaan.

(7) Peserta didik menyimak tujuan pembelajaran pada pertemuan yang berlangsung yang disampaikan guru.

(8) Guru mengaitkan materi pembelajaran teks melaporkan percobaan dengan pengalaman peserta didik juga dengan materi sebelumnya.

(9) Peserta didik menjawab pertanyaan dan mengemukakan pendapatnya yang berkaitan dengan teks melaporkan percobaan yang dilakukan.

(10) Guru memberikan gambaran tentang manfaat mempelajari teks melaporkan percobaan dalam kehidupan sehari-hari.

(11) Peserta didik menyimak kompetensi inti, kompetensi dasar, indikator, dan KKM pada pertemuan yang berlangsung.

(12) Pembagian kelompok belajar.

(13) Peserta didik menyimak mekanisme pelaksanaan pengalaman belajar sesuai dengan langkah-langkah pembelajaran.

\section{Kegiatan Inti (60 Menit)}

1) Mengamati:

(1) Peserta didik mencermati tayangan video teks percobaan Laporan Praktikum Jaringan Xilem.

2) Menanya

(2) Peserta didik bertanya tentang hal-hal yang berkaitan dengan teks melaporkan percobaan (Pertanyaan yang dikemukakan peserta didik dapat menggunakan kata tanya mengapa, bagaimana, apa perbedaannya, apakah, dll)
(3) Dalam kegiatan tanya jawab, guru mentolerir jawaban yang nyeleneh, menghargai setiap jawaban siswa.

3) Mengumpulkan informasi

(4) Secara berkelompok peserta didik mencari informasi tentang struktur teks laporan percobaan Laporan Praktikum Jaringan Xilem

(5) Mencari dan membaca berbagai referensi dari berbagai sumber guna menambah pengetahuan dan pemahaman tentang materi struktur dan ciri kebahasaan teks laporan percobaan

4) Mediskusikan

(6) Peserta didik dan guru secara bersama-sama membahas materi struktur dan ciri kebahasaan teks laporan percobaan jaringan Xilem

5)Mengkomunimaksikan/Mempresentasikan

(7) Peserta didik mengkomunikasikan secara lisan atau mempresentasikan materi struktur dan ciri kebahasaan teks laporan hasil percobaan sesuai dengan pemahamannya.

(8) Masing-masing kelompok melaporkan hasil pembahasan struktur dan ciri kebahasaan teks laporan percobaan (ke depan kelas/presentasi dengan seksama)

(9) Peserta didik berdiskusi. Guru mengawasi jalannya presentasi dan diskusi kelompok, mengomentari penggunaan bahasa yang digunakan siswa. Guru menegur langsung dan memperbaiki kesalahan berbahasa siswa jika ada. Masing-masing kelompok mencoba membahas permasalahan berkenaan dengan struktur dan ciri kebahasaan teks laporan percobaan. Dalam membahas permasalahan, siswa saling mengahargai pendapat, mematuhi aturan-aturan dalam kelompok, dan berkomunikasi dengan baik serta menggunakan bahasa Indonesia yang baik dan benar, penuh kesantunan. Guru menegur dan memperbaiki secara langsung bila ada siswa yang melakukan kesalahan 
berbahasa lisan. Guru juga mencatat nilai karakter setiap siswa.

(10) Peserta didik mengerjakan beberapa soal mengenai materi struktur dan ciri kebahasaan teks laporan percobaan

(11) Icebreak: Agar proses pembelajaran tidak monoton dan untuk memberikan rasa nyaman serta mengurangi kejenuhan, peserta didik diajak untuk berdiri, mengepalkan tangan kanan ke atas. Jika guru berkata senyum, peserta didik menjawab jujur, mandiri, sukses, yes! Hal ini bisa diulang dua sampai tiga kali.

\section{Kegiatan Penutup (10 Menit)}

(1) Peserta didik menyampaikan hasil diskusi tentang materi struktur dan ciri kebahasaan teks laporan percobaan berupa kesimpulan berdasarkan hasil analisis secara lisan, tertulis, atau media lainnya untuk mengembangkan sikap jujur, kritis, toleransi, tanggung jawab. Peserta didik mengungkapkan pendapat dengan sopan.

(2) Peserta didik menyimpulkan butirbutir penting yang muncul dalam kegiatan pembelajaran yang baru dilakukan berupa: Laporan hasil pengamatan secara tertulis tentang struktur dan ciri kebahasaan teks laporan percobaan.

(3) Peserta didik membuat rangkuman pembelajaran hari ini

(4) Peserta didik dengan panduan guru melakukan refleksi. Misalnya menegaskan kembali tentang hal-hal yang perlu diperhatikan ketika menganalisis struktur dan ciri kebahasaan teks laporan percobaan. Guru meminta siswa mengungkapkan kembali tentang apa saja yang sudah diperoleh dalam kegiatan pembelajaran hari ini, mengajak siswa menyimpulkan materi yang telah dipelajari, memberi konfirmasi pada hasil pekerjaan yang sudah dikerjakan oleh siswa melalui sumber buku lain.

(5) Peserta didik menyimak penjelasan guru dengan sungguh-sungguh dan memperbaiki hasil analisisnya. Siswa memperhatikan penjelasan dan komentar guru berkenaan struktur dan ciri kebahasaan teks laporan percobaan.

(6) Peserta didik mencatat informasi tentang tugas untuk pertemuan berikutnya, yaitu melakukan persiapan untuk menyajikan teks laporan percobaan berdasarkan struktur yang benar.

(7) Guru menutup pembelajaran dengan kata-kata motivasi. Bersama siswa, guru mensyukuri kegiatan belajar hari ini dengan harapan memiliki banyak manfaat.

(8) Guru dan siswa mengakhiri kegiatan pembelajaran dengan membaca hamdallah.

(9) Peserta didik sebelum pulang merapikan pakaiannya, tempat duduknya dan memperhatikan kebersihan kelas sebelum beralih ke mata pelajaran berikutnya atau berakhirnya pelajaran.

(10) Guru menanamkan harapan kepada siswa agar memahami sebuah pencapaian positif dan bermanfaat.

(11) Guru menyampaikan kata-kata motivasi terakhir sebelum keluar kelas misalnya kemalasan adalam musuh kita semua.

Pelaksanaan pembelajaran hasil pengembangan sudah diintegrasikan dengan nilai-niai PPK. Hal ini tampak dari mulai kegiatan pendahuluan, kegiatan inti, dan kegiatan penutup. Dalam kegiatan pendahuluan, karakter religius tampak pada butir 1), 2), dan 3). Kegiatan ini diawali dengan berdoa sesuai dengan agama dan kepercayaan masing-masing. Dilanjutkan dengan memeriksa kehadiran dan mendoakan siswa yang tidak hadir karena sakit. Kemudian Guru mengajak siswa untuk senantiasa bersyukur 
atas kesehatan, cuaca/udara yang dianugerahkan Allah SWT. Pada butir 5) karakter religius berkenaan dengan mencintai lingkungan. Karakter nasionalis dalam kegiatan pendahuluan tampak pada butir 4) yang pada intinya bersikap positif pada Bahasa Indonesia. Karakter mandiri tampak pada keberanian siswa memimpin kelas dalam berdoa dan menjadi pembelajar yang tangguh. Penanaman karakter gotong royong ditampilkan dalam kegiatan pembagian kelompok.

Integrasi nilai-nilai PPK dalam kegiatan inti diawali dengan nilai karakter integritas. Siswa setia dengan penuh tanggung jawab mencermati tayangan teks percobaan. Karakter mandiri ditampilkan melalui kegiatan kreativitas tanya jawab. Peserta didik didorong berani bertanya, mengemukakan pendapatnya, dan menjawab pertanyaanpertanyaan baik dari guru maupun dari peserta didik lain. Selain itu, karakter mandiri ditampilkan melalui kegiatan mengkomunikasikan/mempresentasikan hasil menelaah teks laporan percobaan.

Karakter gotong royong terdapat pada kegiatan mengumpulkan informasi dan berdiskusi. Kegiatan ini menonjolkan sikap menghargai, kerjasama, komitmen atas keputusan bersama dan solidaritas. Kegiatan inti diakhiri dengan icebreak berupa penanaman semangat beraktivitas atau bisa juga berupa tayangan video motivasi dari motivator yang digemari remaja.

Nilai-nilai PPK dalam kegiatan penutup berupa nilai religius pada butir 1), 7), dan 8). Dalam kegiatan ini peserta didik menunjukkan sikap toleransi, bersyukur atas kegiatan hari ini, dan diakhiri dengan membaca hamdalah. Nilai karakter nasionalis tampak pada butir 9), guru mengingatkan peserta didik mengenai kerapian pakaian, kerapian tempat duduk, dan kebersihan lingkungan di dalam kelas. Nilai karakter mandiri terdapat pada butir 1), 2), 3), 4). Peserta didik berani menyampaikan hasil diskusi dengan kreatifitasnya membuat rangkuman, dan melakukan refleksi. Karakter integritas ditampilkan melalui kejujuran mengemukakan hasil diskusi dengan penuh tanggung jawab (butir 1)). Butir 9) dan 10) merupakan penguat karakter integritas yang dikemukakan oleh guru berupa harapan kepada siswa agar memahami sebuah pencapaian positif dan bermanfaat. Selain itu guru menyampaikan kata-kata motivasi terakhir sebelum keluar kelas yaitu kemalasan adalah musuh kita semua.

\section{SIMPULAN}

Pengembangan langkah-langkah pembelajaran teks melaporkan percobaan disusun secara rinci sesuai dengan tuntutan kurikulum 2013. Selain itu, langkah-langkah pembelajaran yang dikembangkan juga disertai dengan integrasi nilai-nilai penguatan pendidikan karakter.

Nilai-nilai PPK sangat penting diimplementasikan di kelas untuk memperkuat bakat, potensi, dan talenta peserta didik. Pengembangan nilai-nilai PPK juga diharapkan mampu memperbaiki generasi bangsa.

Langkah-langkah pembelajaran yang terdapat dalam RPP sebaiknya disusun lengkap dan sistematis. Hal ini perlu dilakukan guna memudahkan guru dalam melaksanakan kegiatan pembelajarannya dan diharapkan tujuan pembelajran tercapai dengan baik dan sesuai dengan tuntutan Kurikulum 2013. Pelaksanaan pembelajaran bahasa Indonesia perlu dikembangkan dengan mengintegrasikan nilai-nilai PPK. Pengembangan ini sebaiknya ditampilkan secara tertulis dalam langkah-langkah pembelajaran mulai dari kegiatan pendahuluan, kegiatan inti sampai kegiatan penutup. Sekali lagi, hal ini penting untuk memudahkan guru dalam praktik pembelajaran di kelas.

Guru bahasa Indonesia hendaknya mengembangkan pelaksanaan kegiatan pembelajaran berorientasi PPK untuk semua materi pembelajaran. 


\section{DAFTAR PUSTAKA}

Borg, R Walter dan Gall Meredith D. 1989. Educational Research An Introduction. Longman: Fifth Edition.

Emilia, Emi. 2016. Pendekatan Berbasis Teks dalam Pengajaran bahasa Inggris. Bandung: Kiblat.

Kemdikbud. 2015. Permendikbud No 23 Tahun 2015 tentang Penumbuhan Budi Pekerti.

Kemdikbud.2016. Permendikbud No. 22 Tahun 2016 tentang Standar Proses Pendidikan Dasar dan Menengah. Jakarta: Kemdikbud.

Kemdikbud RI. 2017. Konsep dan Pedoman Penguatan Pendidikan Karakter Tingkat Sekolah Dasar dan Sekolah Menengah Pertama. Tersedia pada http://cerdasberkarakter.kemdikbud.go.id. Diakses 20 Februari 2017. Resposibility. Bantam Books, New York.

M.S., Mahsun. 2018. Pembelajaran Bahasa Indonesia Berbasis Teks. Edisi Kedua. Depok:PT Raja Grafindo Persada.

Mulyanti, Sri. 2012. Model Pembelajaran Keterampilan Berbahasa Indonesia Berorientasi Pendidikan Karakter. Upi Bandung: Disertasi.

Priyatni, Endah Tri. 2015. Desain Pembelajaran Bahasa Indonesia dalam Kurikulum 2013. Jakarta: PT Bumi Aksara.

Samani dan Hariyanto. 2011. Konsep dan Model Pendidikan Karakter. Bandung: PT Remaja Rosdakarya.

Sugiyono. (2011). Metode Penelitian Kuantitatif, Kualitatif, dan $R \&$ D. Bandung: Alfabeta

Trianto, Agus,dkk. 2018. Bahasa Indonesia: Wahana Pengetahuan Kelas IX. Depok: CV. Arya Putra ( Buku Siswa)

Trianto, Agus,dkk. 2018. Buku Guru Bahasa Indonesia SMP/MTS Kelas IX. Jakarta: Kemdikbud (http://smkpenanusantara.blogspot.com/2016/12/pengertian-teks-laporan$\underline{\text { struktur-teks.html }}$

Undang-Undang. 2003. Undang-Undang Nomor 20, tahun 2003 tentang Sistem Pendidikan Nasional. Jakarta. 